\title{
Epidemiological study in a new focus of cutaneous leishmaniasis in the Islamic Republic of Iran
}

M.R. Yaghoobi-Ershadi, ${ }^{1}$ A.A. Akhavan, ${ }^{1}$ A. V. Zahraei-Ramazani, ${ }^{2}$ M.R. Abai, ${ }^{1}$ B. Ebrahimi, ${ }^{1}$ R. Vafaei-Nezhad, ${ }^{3}$ A.A. Hanafi-Bojd ${ }^{4}$ and R. Jafari ${ }^{5}$

$$
\begin{aligned}
& \text { دراسة وبائية في بؤرة جديدة لداء الليشمانيات البحلدية في إيران }
\end{aligned}
$$

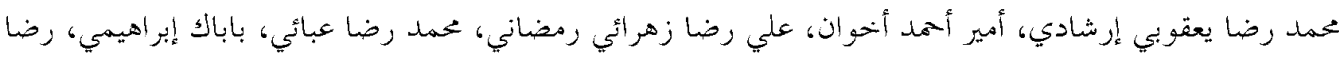

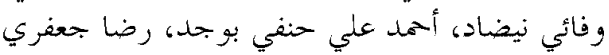

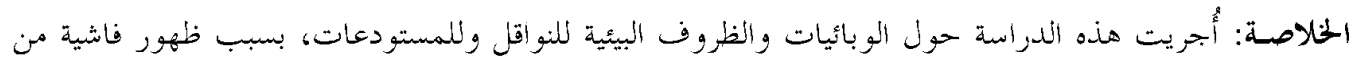

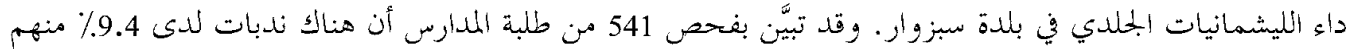

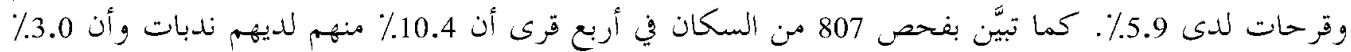

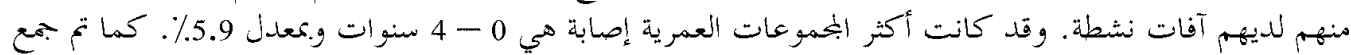

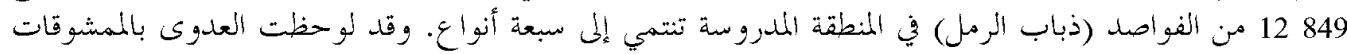

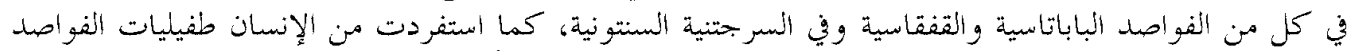

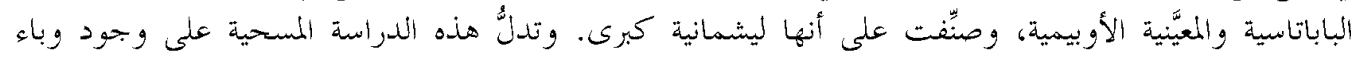

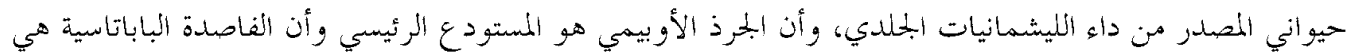

$$
\begin{aligned}
& \text { الناقل الرئيسي. }
\end{aligned}
$$

ABSTRACT An outbreak of cutaneous leishmaniasis (CL) in Sabzevar county prompted this study of the epidemiology and the ecology of vectors and reservoirs. Examination of 541 schoolchildren showed rates of $9.4 \%$ for scars and $5.9 \%$ for ulcers. Among 807 inhabitants of 4 villages, $10.4 \%$ had scars and $3.0 \%$ had active lesions. The most highly infected age group was $0-4$ years with a rate of $5.9 \%$. A total of 12849 sandflies representing 7 species were collected in the study area. Leptomonad infection was found in Phlebotomus papatasi, P. caucasicus and Sergentomyia sintoni. Parasites from man, P. papatasi and Rhombomys opimus, were isolated and characterized as Leishmania major. Based on this survey, this is an epidemic of zoonotic $\mathrm{CL}$, with $R$. opimus the main reservoir host, and $P$. papatasi the main vector.

\begin{abstract}
Etude épidémiologique dans un nouveau foyer de leishmaniose cutanée en République islamique d'Iran

RESUME Une flambée de leishmaniose cutanée dans le comté de Sebzevar a incité à réaliser cette étude sur l'épidémiologie et l'écologie des vecteurs et des réservoirs. L'examen de 541 écoliers a révélé des taux de $9,4 \%$ pour les cicatrices et 5,9\% pour les ulcères. Parmi les 807 habitants de 4 villages, $10,4 \%$ avaient des cicatrices et $3,0 \%$ avaient des lésions actives. Le groupe d'âge le plus infecté était celui de 0 à 4 ans avec un taux de 5,9\%. Au total, 12849 phlébotomes représentant 7 espèces ont été prélevés dans la zone d'étude. On a trouvé que Phlebotomus papatasi, P. caucasicus et Sergentomyia sintoni étaient infectés par un leptomonas. Les parasites de l'homme, P. papatasi et Rhombomys opimus, ont été isolés et caractérisés comme Leishmania major. D'après cette étude, il s'agit d'une épidémie de leishmaniose cutanée zoonosique, avec $R$. opimus comme principal hôte réservoir, et $P$. papatasi comme principal vecteur.
\end{abstract}

${ }^{1}$ School of Public Health and Institute of Public Health Research; ${ }^{2}$ Isfahan Training and Health Research Centre; ${ }^{4}$ Bandar Abbas Training and Health Research Centre; ${ }^{5}$ Yazd Training and Health Research Centre; Tehran University of Medical Sciences, Tehran, Islamic Republic of Iran.

${ }^{3}$ Department of Public Health, Sabzevar University of Medical Sciences, Sabzevar, Islamic Republic of Iran.

المجلة الصحية لشرق المتوسط، منظمة الصحة العالمية، المجلد التاسع، العدد ع، ب... 


\section{Introduction}

Cutaneous leishmaniasis (CL) is still a great health problem in Iran. At a particular geographical location where the disease has been sporadic in the past, it has grown to epidemic proportions. It has even spread into sites where it did not previously exist [1]. Recently a new focus of CL was found in villages in Jovein, Sabzevar county in northeastern Iran. A preliminary survey showed a rate of $9.4 \%$ for ulcers in November 2000 (Institute of Public Health Research, unpublished data).

Following the establishment of Sarakhs free trade zone and the opening of the Silk Road, economic development is well under way in the area. This attracts frequent visitors, many of whom are non-immune, and they may be exposed to bites of infected sandflies during the active season. The epidemiological features of $C L$ in this area are unknown, consequently, in-depth epidemiological studies are needed.

The objective of this investigation was to determine the prevalence and incidence of the disease, to study the reservoirs and the vectors, and the nature of the parasite in this new focus for the implementation of future control measures.

\section{Methods}

\section{Study area}

The investigation was carried out from 30 September 2001 to 30 November 2002 in 4 villages, Zirabad, Bahrabad, Gharzi and Kalate-Andadeh, in the rural district of Jovein and also in 4 villages, Kalateh-Mazinan, Mazinan, Kahak and Bahman-Abad, in the rural district of Davarzan, Sabzevar county, Khorassan province, in the northeast of the Islamic Republic of Iran.

Sabzevar county $\left(57^{\circ} 4^{\prime} \mathrm{N}, 36^{\circ} 13^{\prime} \mathrm{E}\right)$ is situated in the north of the central salt desert, $224 \mathrm{~km}$ west of Mashhad. The county had a population of 442389 in 2000 . The climate is moderate in mountainous areas but very hot and dry in the desert.

In 2001, the maximum mean monthly temperature was $31.5^{\circ} \mathrm{C}$ (July) and the minimum was $7.4^{\circ} \mathrm{C}$ (February). The total annual rainfall was $112.1 \mathrm{~mm}$, with a monthly minimum of $0.2 \mathrm{~mm}$ (September) and maximum of $49.0 \mathrm{~mm}$ (December). The minimum mean monthly relative humidity was $22 \%$ (July) and the maximum was 68\% (December).

Buildings are made of bricks and girders (35.3\%), sun dried bricks and mud (18.4\%), some with a wooden roof covered by reed (46.3\%). Many of them were newly constructed. There are 5 primary schools and 1 guidance school in the selected villages in Jovein rural district and 5 primary schools, 4 guidance schools and 2 high schools in Davarzan rural district. Both districts are located in the plain. The villages are about $7 \mathrm{~km}$ from the railway lines and less than $500 \mathrm{~m}$ from the rodent burrows. A sugar refinery is located at a distance of less than $20 \mathrm{~km}$ from the study area. Farming is the main occupation and some people keep cows and sheep.

The soil of the area is soft clay and generally a little salty and in some parts sandy. Wheat, barley, sugarbeet, alfalfa, cumin, cotton, tomatoes, maize, beans, melon, watermelon, sunflowers, sesame plants and peas are cultivated, with the main crop being sugarbeet (70\%). The Kal Shur river runs at a distance of $3 \mathrm{~km}$ from the infected villages.

\section{Population studies}

The study was carried out in two population groups: a) all schoolchildren and b) the inhabitants of the selected villages. For the first group, a list of all the schools was obtained from the Department of Education.

المجلة الصحية لشرق المتوسط، منظمة الصحة العالمية، المجلد التاسع، العدد ع، ب... 
Each class was visited and all students were questioned and examined clinically for the presence of ulcers or scars. For each child having an ulcer or scar, a form was completed to record information such as name, address, age, sex, number of ulcers or scars, date and place of acquiring the disease.

For the second group, 160 households in the villages were randomly selected. All members of the selected households were examined clinically, as described for the students, during November and December. Samples were taken from active lesions and inoculated subcutaneously at the base of the tail of BALB/C mice (2 mice for each). Parasites were re-isolated from infected mice and cultured in Novy-NicolleMacNeal (NNN) medium plus liver infusion tryptophase (LIT) medium (both manufactured by the Protozoology Unit, Department of Medical Parasitology). The random amplified polymorphic DNA polymerase chain reaction (RAPD-PCR) technique [2] was used for identification of parasites.

All patients with active lesions who took part in this research project had given informed consent. For the schoolchildren, this was obtained from the Department of Education and also the principal of the school. All the risks had been explained to them by the principal investigator before the beginning of the programme. Participants could choose to withdraw from the study at any time if they wished.

\section{Collection and examination of rodents}

Rodents were caught in 40 live traps baited with cucumber and dates at the end of the high season for infection. In the laboratory, 4 impression smears were prepared from the ears of each rodent, fixed in methanol and stained by the standard Geimsa meth- od, then examined microscopically. Samples from infected rodents were injected subcutaneously at the base of the tail of inbred BALB/c mice to identify the parasite. Parasites were re-isolated from infected mice and cultured in NNN + LIT medium containing $200 \mathrm{IU}$ penicillin per $\mathrm{mL}$, incubated at $20-21^{\circ} \mathrm{C}$ and monitored every 4 days. The RAPD-PCR technique was used for the identification of parasites.

\section{Collection of sandflies}

Sandflies were collected once a month from fixed sites indoors (bedrooms, stables, storerooms, etc) and outdoors (rodent burrows), using 30 sticky traps (castor oil-coated white papers $20 \mathrm{~cm} \times 30$ $\mathrm{cm}$ ) from the beginning to the end of the active season (early June-October). For species identification, sandflies were mounted in Puri's medium (produced in the medical entomology department) [3] and identified after 24 hours using the keys of Theodor and Mesghali [4], then they were mounted and segregated by sex.

\section{Detection of natural leptomonad infection in sandflies}

Sandfly collections were made at the end of transmission season in the selected villages by putting sticky traps and funnel traps in the rodent burrows and by aspirator inside houses. CDC light traps were also used in the last 2 weeks of September near rodent burrows. Collections were transferred to the laboratory at Sabzevar health centre for dissection. Blood-fed females collected indoors were kept alive for 3-4 days to allow blood digestion and then dissected. All fed and gravid females collected from rodent burrows were dissected in a fresh drop of sterile saline and examined microscopically the same day for natural flagellate infections. Once flagellates were seen, a few drops of saline were added to the prepara-

المجلة الصحية لشرق المتوسط، منظمة الصحة العالمية، المجلد التاسع، العدد ؟، ب... 
tion, which was then aspirated into a sterile syringe and injected subcutaneously into the base of the tail of $2 \mathrm{BALB} / \mathrm{c}$ mice. Parasites were later reisolated from infected mice and cultured in 2-4 tubes of NNN biphasic medium with penicillin (200 IU per $\mathrm{mL}$ ). Culture tubes were incubated at $20^{\circ} \mathrm{C}$ and subcultured every 15 days. All female sandflies were identified by the morphology of the pharyngeal armature and of the spermatheca [4]. The RAPD-PCR technique was used for identification of parasites.

\section{Susceptibility tests}

The susceptibility status of $P$. papatasi to DDT, permethrin and propoxur was studied in the field surveys during August 2002, following the WHO standard method [5] and using impregnated papers supplied by WHO.

\section{Statistical analysis}

The z-test was used to determine any statistically significant differences in disease prevalence between females and males and between those $<10$ years and those $\geq 10$ years. For the students, the $\chi^{2}$ and Fisher tests were used for the same purpose. The data were analysed using a statistical package (Probit 79) and graphs were prepared using Harvard Graphics ${ }^{\circledR}$ version 3.

\section{Results}

\section{Jovein rural district}

Prevalence among 807 inhabitants of the 4 villages studied was $10.4 \%$ for scars and $3.0 \%$ for active lesions (Table 1 ). The highest rate for those having scars was $15.8 \%$ in the age group 5-9 years and the lowest rate was $2.0 \%$ in the age group $0-4$ years. Prevalence of scars was $11.2 \%$ in those $<10$ years and $10.2 \%$ for those $\geq 10$ years.
Prevalence of ulcers among the inhabitants was $3.0 \%$. The most highly infected age group was $0-4$ with a rate of $5.9 \%$ and the lowest rate was $1.7 \%$ in the age group of 20-24 years. Those $<10$ years showed a rate of $3.3 \%$ for ulcers; this was $2.9 \%$ for those $\geq 10$ years old. The Fisher test showed no statistically significant differences in the prevalence of CL between these two age groups. No statistically significant difference was observed between males and females in the different age groups regarding the prevalence of scars or active lesions $(\alpha=5 \%)$. More than $52 \%$ of the people with active lesions had 1 ulcer, $17.4 \%$ had 2 and the rest had $\geq 3$. Hands, legs and face were the parts of the body most infected, with $40.0 \%, 38.2 \%$ and $20.0 \%$ of the active lesions respectively.

A total of 541 children aged 7-14 years in all the primary schools in the villages studied, 270 girls (49.9\%) and 271 boys (50.1\%), were examined physically for the presence of active CL lesions or scars. The overall scar rate was $9.4 \%$ and the prevalence of ulcers was $5.9 \%$ (Table 2). The highest prevalence of active lesions was $9.1 \%$ for 13 year olds and the lowest was $4.0 \%$ for 9 year olds. Statistically significant differences were observed in prevalence of ulcers by sex, prevalence in boys being more than twice that in girls $\left(\chi_{1}^{2}=\right.$ 4.74, $P=0.0295)$. In children with active lesions, $45.5 \%$ had 1 lesion, $21.2 \%$ had 2 lesions and $33.3 \%$ had $\geq 3$ lesions. Hands, legs and face were the most infected parts of the body with $48.2 \%, 25.9 \%$ and $22.2 \%$ of the ulcers respectively.

Parasites from 7 patients with ulcers were injected subcutaneously at the base of the tail of 15 BALB/c mice. In 4 of them (26.7\%) nodules and ulcers containing numerous amastigotes appeared at the site of inoculation 62-68 days after injection. Par-

المجلة الصحية لشرق المتوسط، منظمة الصحة العالمية، المجلد التاسع، العدد ع، ب... 
Table 1 Prevalence of cutaneous leishmaniasis by age and sex in Jovein rural district, November-December 2001

\begin{tabular}{|c|c|c|c|c|c|c|c|c|c|}
\hline \multirow{2}{*}{$\begin{array}{l}\text { Age group } \\
\text { (years) }\end{array}$} & \multicolumn{3}{|c|}{ No. observed } & \multicolumn{3}{|c|}{ Prevalence of scars (\%) } & \multicolumn{3}{|c|}{ Prevalence of active lesions (\%) } \\
\hline & M & $\mathbf{F}$ & Total & M & $\mathbf{F}$ & Total & M & $\mathbf{F}$ & Total \\
\hline $0-4$ & 23 & 28 & 51 & 4.3 & 0 & 2.0 & 4.3 & 7.1 & 5.9 \\
\hline $5-9$ & 57 & 44 & 101 & 17.5 & 13.6 & 15.8 & 1.8 & 2.3 & 2.0 \\
\hline $10-14$ & 83 & 82 & 165 & 9.6 & 13.4 & 11.5 & 2.4 & 1.2 & 1.8 \\
\hline $15-19$ & 74 & 62 & 136 & 6.8 & 12.9 & 9.6 & 0 & 0 & 0 \\
\hline $20-24$ & 30 & 29 & 59 & 6.7 & 0 & 3.4 & 3.3 & 0 & 1.7 \\
\hline$\geq 25$ & 141 & 154 & 295 & 12.8 & 9.7 & 11.2 & 4.3 & 5.8 & 5.1 \\
\hline All ages & 408 & 399 & 807 & 10.8 & 10.0 & 10.4 & 2.7 & 3.3 & 3.0 \\
\hline
\end{tabular}

$M=$ male,$F=$ female.

Prevalence of scars or active lesions was not significantly different between males and females in different age groups $(\alpha=5 \%)$.

\begin{tabular}{|c|c|c|c|c|c|c|c|c|c|}
\hline \multirow[t]{2}{*}{ Sex } & \multicolumn{8}{|c|}{ Age (years) } & \multirow[t]{2}{*}{ Total } \\
\hline & 7 & 8 & 9 & 10 & 11 & 12 & 13 & 14 & \\
\hline \multicolumn{10}{|l|}{ Male } \\
\hline No. observed & 52 & 28 & 55 & 43 & 50 & 30 & 7 & 6 & 271 \\
\hline Scars $(\%)$ & 1.9 & 17.9 & 7.3 & 9.3 & 10.0 & 10.0 & 28.6 & 16.7 & 9.2 \\
\hline Active lesions (\%) & 15.4 & 0 & 7.3 & 7.0 & 6.0 & 6.7 & 28.6 & 0 & $8.1^{\mathrm{a}}$ \\
\hline \multicolumn{10}{|l|}{ Female } \\
\hline No. observed & 48 & 30 & 44 & 45 & 52 & 26 & 15 & 10 & 270 \\
\hline Scars (\%) & 2.1 & 10.0 & 6.8 & 6.7 & 21.2 & 11.5 & 13.3 & 0 & 9.6 \\
\hline Active lesions (\%) & 2.1 & 10.0 & 0 & 2.2 & 3.8 & 7.7 & 0 & 10.0 & $3.7^{\mathrm{a}}$ \\
\hline \multicolumn{10}{|l|}{ Both sexes } \\
\hline No. observed & 100 & 58 & 99 & 88 & 102 & 56 & 22 & 16 & 541 \\
\hline Scars (\%) & 2.0 & 13.8 & 7.1 & 8.0 & 15.7 & 10.7 & 18.2 & 6.3 & 9.4 \\
\hline Active lesions (\%) & 9.0 & 5.2 & 4.0 & 4.5 & 4.9 & 7.1 & 9.1 & 6.3 & 5.9 \\
\hline
\end{tabular}

asites were reisolated from infected mice and cultured in NNN plus LIT medium containing $200 \mathrm{IU}$ penicillin per $\mathrm{mL}$, incubated at $20-21^{\circ} \mathrm{C}$ and monitored for growth every 4 days from day 4 . All positive cultures were subcultured every 15 days. Examination of 4 isolates from human indigenous cases identified them as Leishmania major.

A total of 56 small mammals were captured by Sherman traps and examined during October-November 2001 and 
August- September 2002. Of the 4 species of small mammals found in the area, Rhombomys opimus (great gerbil) (80.4\%) was predominant; the other 3 were Nesokia indica (12.5\%), Meriones libycus (3.6\%) and Hemiechinus auritis (3.5\%). Four impression smears were prepared from the ears of each rodent, fixed in methanol, stained by the standard Giemsa method and examined under the microscope. Seven out of $45 R$. opimus were found to be infected with Leishmania (15.6\%). Parasites from the 7 infected animals were injected subcutaneously at the base of the tail of 19 BALB/ c mice. Nodules and ulcers containing numerous amastigotes appeared within 15 days in 5 mice, and within 5 days cultures from the lesions of 5 different infected great gerbils contained profuse promastigotes of L. major.

During April-October 2002, 8726 adult sandflies (7558 from outdoors and 1168 from indoor resting places) were collected and identified (Table 3). The following 6 species were found in bedrooms, storerooms and toilets: Phlebotomus papatasi (32.4\%); P. caucasicus (1.7\%); P. ansarii
(0.6\%); Sergentomyia sintoni (64.6\%), S. grekovi $(0.6 \%)$ and $S$. sumbarica $(0.1 \%)$. In the rodent burrows, $P$. papatasi (8.5\%); P. ansarii (7.6\%); P. caucasicus (8.9\%); P. sergenti $(0.2 \%)$, S. sintoni $(74.3 \%)$ and $S$. grekovi $(0.5 \%)$ were collected. Sandflies common indoors were $P$. papatasi and $S$. sintoni and outdoors $S$. sintoni was common. Phlebotomus papatasi started to appear in April and disappeared at the end of October. There are two peaks in the density curve of this species, one in June and the second in August (Figures 1 and 2). The decrease in sandfly density at the end of October was most probably due to the cold weather. The density of other species was very low so it was impossible to determine the monthly density.

Phlebotomus papatasi (155), P. caucasicus (88), P. sergenti (3), P. ansarii (3), $P$. keshishiani (3) and S. sintoni (108) were collected in the vicinity of rodent burrows and were dissected during AugustSeptember 2002. The results of the dissections showed that $P$. papatasi (4.5\%), P. caucasicus (2.3\%) and S. sintoni $(2.8 \%)$ were infected with leptomonads

\begin{tabular}{|c|c|c|c|c|c|c|c|c|}
\hline $\begin{array}{l}\text { Collection } \\
\text { sites }\end{array}$ & $\begin{array}{c}P . \\
\text { papatasi }\end{array}$ & $\begin{array}{c}P . \\
\text { caucasicus }\end{array}$ & $\begin{array}{c}P . \\
\text { ansarii }\end{array}$ & $\begin{array}{c}P . \\
\text { sergenti }\end{array}$ & $\begin{array}{c}S . \\
\text { sintoni }\end{array}$ & $\begin{array}{c}S . \\
\text { grekovi }\end{array}$ & $\begin{array}{c}\text { S. } \\
\text { sumbarica }\end{array}$ & Total \\
\hline \multicolumn{9}{|l|}{ Indoors } \\
\hline No. & 378 & 20 & 7 & 0 & 755 & 7 & 1 & 1168 \\
\hline$\%$ & 32.4 & 1.7 & 0.6 & - & 64.6 & 0.6 & 0.1 & 13.4 \\
\hline \multicolumn{9}{|l|}{ Outdoors } \\
\hline No. & 643 & 676 & 576 & 12 & 5617 & 34 & 0 & 7558 \\
\hline$\%$ & 8.5 & 8.9 & 7.6 & 0.2 & 74.3 & 0.5 & - & 86.6 \\
\hline \multicolumn{9}{|l|}{ Total } \\
\hline No. & 1021 & 696 & 583 & 12 & 6372 & 41 & 1 & 8726 \\
\hline$\%$ & 11.7 & 8.0 & 6.7 & 0.1 & 73.0 & 0.5 & 0.01 & 100 \\
\hline
\end{tabular}

المجلة الصحية لشرق المتوسط، منظمة الصحة العالمية، المجلد التاسع، العدد ع، ب... 


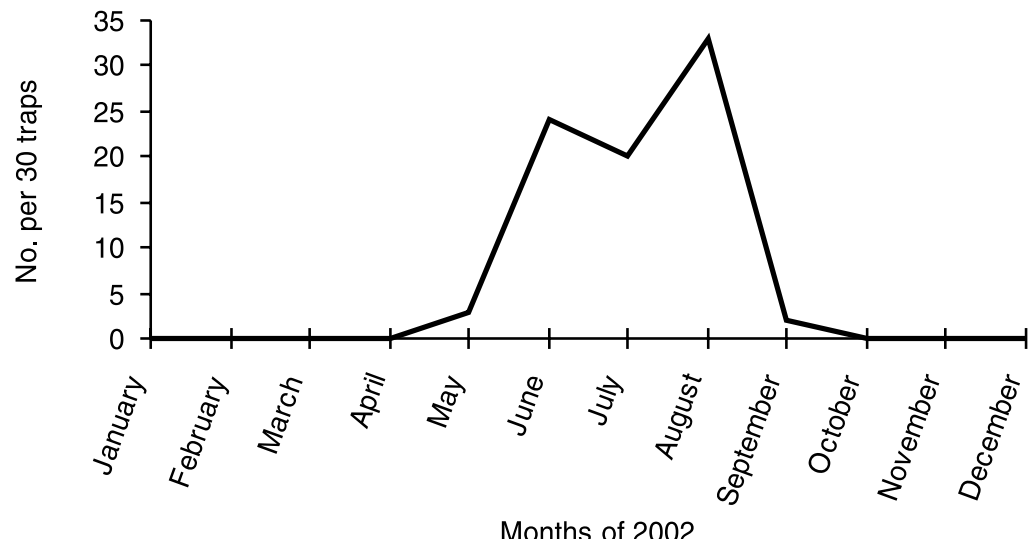

Figure 1 Monthly prevalence of $P$. papatasi in Jovein rural district, Sabezvar county (indoors)

(Table 4). Besides gut infection, leptomonads were seen in the oesophagus of 4 (57.1\%) and in the heads of $2(28.6 \%)$ of 7 positive $P$. papatasi. It is concluded that the promastigotes in $P$. papatasi were in metacyclic form, could migrate to the fo- regut and could be transmitted by the mouthparts of this sandfly in the area. We dissected $P$. papatasi (110), P. caucasicus (6), P. sergenti (2) and S. sintoni (2) from indoors at the same time. All were found to be negative.

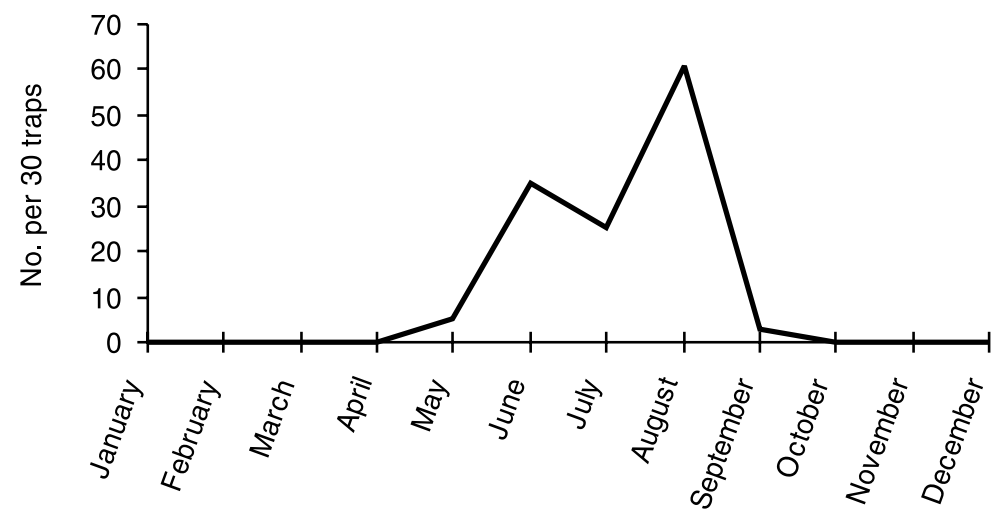

Months of 2002

Figure 2 Monthly prevalence of $P$. papatasi in rodent burrows of Jovein rural district, Sabzevar county

المجلة الصحية لشرق المتوسط، منظمة الصحة العالمية، المجلد التاسع، العدد ؟، ب. ب. 


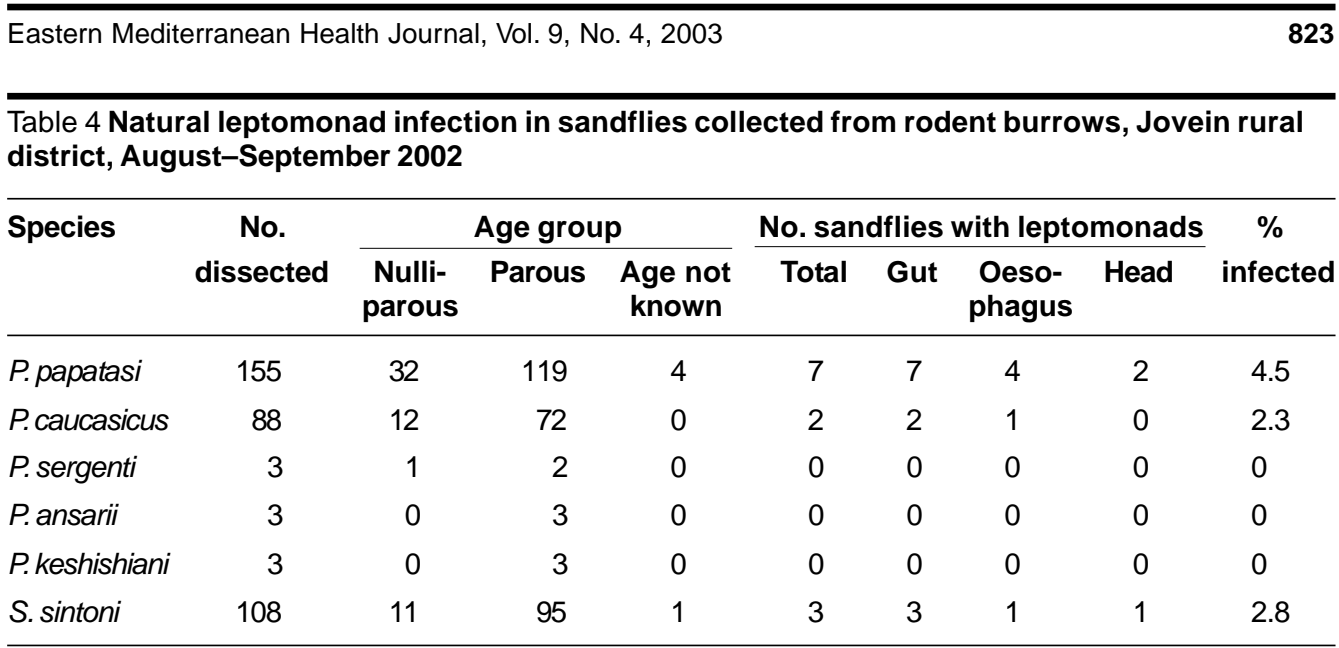

Some females that had oviposited all of their eggs had accessory glands devoid of identifiable granules, so recognizing parous from nulliparous sandflies was impossible.

Promastigotes from 5 heavily infected $P$. papatasi collected from rodent burrows were injected subcutaneously into the tail bases of $2 \mathrm{BALB} / \mathrm{c}$ mice each. Three of these 10 mice (30\%) became infected; nodules and ulcers containing numerous amastigotes developed at the site of inoculation 12 days after injection. By 5 days after inoculation, promastigotes had grown well in 4 of 6 NNN cultures inoculated with parasites from infected mice. The other 2 cultures were uncontaminated and no promastigotes were observed. Four different isolates were characterized as L. major.

A total of 335 fed $P$. papatasi were collected by aspirator from indoors in 3 villages in the first half of September 2002. The mortality rates for $4.0 \%$ DDT after 3.75 , $7.50,15.00,30.00$ and 60.00 minutes of exposure time followed by 24 hours recovery time were $0 \%, 7.7 \%, 41.0 \%, 74.3 \%$ and $100 \%$ respectively in the study area.

A total of 161 fed $P$. papatasi were also tested against permethrin $0.25 \%$ and propoxur $0.10 \%$. The mortality rates after 60 minutes exposure time followed by 24 hours recovery time were $100 \%$ for both. It is concluded that $P$. papatasi in the area is susceptible to DDT, permethrin and propoxur.

\section{Davarzan rural district}

A study of prevalence among 970 inhabitants showed $0.9 \%$ for scars. There were no ulcers among the residents during November-December coincident with the appearance of new cases in the area. The Fisher test showed no statistically significant differences in the prevalence of scars by sex.

A total of 652 children aged 6-18 years, 312 girls (47.9\%) and 340 boys (52.1\%), from all schools in the villages studied were examined physically for the presence of active lesions or scars of CL. The overall scar rate was $0.3 \%$. None of the students had ulcers.

A total of 4123 adult sandflies (2475 from outdoors and 1648 from indoor resting places) were collected and identified in the rural district of Davarzan (Table 5). The following 4 species were found in bedrooms, storerooms and toilets: P. papatasi (14.7\%), P. sergenti (8.7\%), S. sintoni (76.3\%) and S. grekovi (0.3\%). In the rodent burrows, P. papatasi (8.7\%), P. ser-

المجلة الصحية لشرق المتوسط، منظمة الصحة العالمية، المجلد التاسع، العدد ع، ب...T 


\begin{tabular}{|c|c|c|c|c|c|c|}
\hline $\begin{array}{l}\text { Collection } \\
\text { sites }\end{array}$ & P. papatasi & P. sergenti & $\begin{array}{l}\text { Species of sa } \\
\text { S. sintoni }\end{array}$ & $\begin{array}{l}\text { dfly } \\
\text { S. grekovi }\end{array}$ & S. sumbarica & Total \\
\hline \multicolumn{7}{|l|}{ Indoors } \\
\hline No. & 242 & 144 & 1257 & 5 & 0 & 1648 \\
\hline$\%$ & 14.7 & 8.7 & 76.3 & 0.3 & - & 39.9 \\
\hline \multicolumn{7}{|l|}{ Outdoors } \\
\hline No. & 215 & 1158 & 1100 & 1 & 1 & 2475 \\
\hline$\%$ & 8.7 & 46.8 & 44.4 & 0.04 & 0.04 & 60.1 \\
\hline \multicolumn{7}{|l|}{ Total } \\
\hline No. & 457 & 1302 & 2357 & 6 & 1 & 4123 \\
\hline$\%$ & 11.1 & 31.6 & 57.2 & 0.15 & 0.02 & 100 \\
\hline
\end{tabular}

genti (46.8\%), S. sintoni (44.4\%), S. sumbarica $(0.04 \%)$ and S. grekovi $(0.04 \%)$ were collected. Sandflies common indoors were $S$. sintoni and $P$. papatasi but in rodent burrows $P$. sergenti and $S$. sintoni were the dominant species. Phlebotomus papatasi (8), $P$. sergenti (2) and S. sintoni (1) were collected from rodent burrows during September 2002 and dissected. All were found to be negative for leptomonads. We also dissected P. papatasi (57), P. sergenti (1) and $S$. sintoni (1) from indoors at the same time but none of these appeared to be infected.

During August-September 2002, only 5 $N$. indica were captured by Sherman traps near the study villages. No leishmanial infection was found on the ears in microscopic examination.

\section{Discussion}

Although CL has been present in some areas of Jovein and Davarzan rural districts in recent years, this is the first time that an endemic focus of zoonotic CL has been identified.
In the school survey, prevalence of active lesions among boys was more than 2 times that of girls. This may be because boys worked on farms during summer and were exposed to the bite of infected sandflies in the evening and at night.

Our findings suggest that $R$. opimus is the main reservoir host of zoonotic CL and the principal source of human infection in the area north-west of Sabzevar city. This species has been reported as the major reservoir of zoonotic CL in other endemic areas near Sabzevar county, such as Esfarayen, Jajarm and Shahrud (approximate distances of these foci from Sabzevar are $80-250 \mathrm{~km}$ ) [6-10]. There are many active colonies of $R$. opimus around some of the infected villages.

Based on our observations in this survey, most of the rodents had diurnal activities and many of them were trapped during the morning up to 10.00 . It should be mentioned that a number of different kinds of traps, e.g. Tomahawk traps, have been used for catching Gerbillidae in the Islamic Republic of Iran during recent years but Sherman traps proved best for the purpose. Owing to the limited number of colonies of 
Gerbellidae present and the existence of $N$. indica, which is an accidental reservoir host of zoonotic CL in our country, near the study area, no sandfly infection was found in Davarzan rural district.

The results of this survey indicate that we are dealing with an epidemic of zoonotic CL in Jovein rural district, Sabzevar county, with $R$. opimus as the reservoir host and $P$. papatasi as vector among rodents and probably as the vector to man. This new focus should be added to the list of zoonotic CL foci in the Islamic Republic of Iran. The occurrence of this outbreak of zoonotic CL in the study villages may be connected with the construction of buildings near rodent colonies, the habit of sleeping in the yard during the summer, lack of good sanitation, construction of bedrooms and sitting rooms with mat-like roofs close to stables, presence of manure in some villages and the rapid agricultural development in the area, especially growing sugarbeet. This crop is a preferred food of Gerbillidae rodents.

Sabzevar county is located on a transit road to Turkmenistan, Uzbekistan and Kazakhstan with moderate freight traffic, which is likely to increase in the future. Truck drivers stopping off in the area could be at risk of getting the disease and possibly transmitting the infection. Meanwhile the south of the county is also prone to outbreaks of the disease and new epidemics may occur in different foci in the coming years.

It is essential for the health authorities to take strong measures to control epidemics and prevent them spreading to neighbouring villages. The control of zoonotic CL ultimately rests on close cooperation between Universities of Medical Sciences, health centres and the government.

\section{Acknowledgements}

We are grateful to Professor Dr Nadim for his kind comments on the manuscript, $\mathrm{Mr}$ H. Abdoli, Dr A.R. Jalali-Zand and M.H. Arandian of the leishmaniasis unit at the Isfahan Training and Health Research Centre for their excellent assistance in carrying out this programme. The authors would like to thank Dr M. Mohebali (parasitology laboratory, School of Public Health) for parasite characterization by RAPD-PCR. Our appreciation is also offered to Dr M. Gooya and Dr B. Hooshmand from the Disease Management Centre, Ministry of Health and Medical Education and the staff of the Disease Control Office, Sabzevar University of Medical Sciences for their close collaboration.

This investigation received technical and financial support from the joint WHO Eastern Mediterranean Region (EMRO), Division of Communicable Diseases (DCD) and the WHO Special Programme for Research and Training in Tropical Diseases (TDR): the EMRO/DCD/TDR Small Grants Scheme for Operational Research in Tropical and Communicable Diseases, and partly by the School of Public Health and Institute of Public Health Research, Tehran University of Medical Sciences.

\section{References}

1. Yaghoobi-Ershadi MR et al. Epidemiological study in a new focus of cutaneous leishmaniasis due to Leishmania major in Ardestan town, central Iran. Acta tropica, 2001, 79:115-121.
2. Noyes $H$, Belli A, Maingon R. Appraisal of various RAPD-PCR primers for Leishmania identification. American journal of tropical medicine and hygiene, 1996, 55:98-105.

المجلة الصحية لشرق المتوسط، منظمة الصحة العالمية، المجلد التاسع، العدد ع، ب...T 
3. Smart J, Jordan K, Whittick RJ. A handbook for the identification of insects of medical importance, 4th ed. London, British Museum (Natural History), 1965: 285-8.

4. Theodor O, Mesghali A. On the Phlebotominae of Iran. Journal of medical entomology, 1964, 1:285-300.

5. Instructions for determining the susceptibility or resistance of adult blackflies, sandflies and biting midges to insecticides. Geneva, World Health Organization, 1981 (WHO/VBC/810).

6. Seyedi-Rashti MA, Nadim A. Epidemiology of cutaneous leishmaniasis in Iran. B. Khorassan area. Part I. The reservoirs. Bulletin de la societe de pathologie exotique et de ses filiales, 1967, 60:510-8.

7. Mesghali A, Seyedi-Rashti MA, Nadim A. Epidemiology of cutaneous leishmaniasis in Iran. Part II. Natural leptomonad in- fection of sandflies in the Meshed and Lotfabad areas. Bulletin de la societe de pathologie exotique et de ses filiales, 1967, 60:514-7.

8. Nadim A, Seyedi-Rashti MA, Faghih MA. Epidemiology of cutaneous leishmaniasis in Iran:B. Khorassan. Part III. Human infection. Bulletin de la societe de pathologie exotique et de ses filiales, 1969, 62(4):702-10.

9. Javadian $\mathrm{E}$ et al. Epidemiology of cutaneous leishmaniasis in Iran. B. Khorassan. Part V. Report on a focus of zoonotic cutaneous leishmaniasis in Esferayen. Bulletin de la societe de pathologie exotique et de ses filiales, 1976, 69(2):140-3.

10. Nadim A, Seyedi-Rashti MA. A brief review of the epidemiology of various types of leishmaniasis in Iran. Acta medica Iranica, 1971, 14:99-106. 